\title{
POSTULAT KESEJAJARAN EUCLID DALAM TINJAUAN SEJARAH
}

\author{
Agung Prabowo \\ Fakultas Sains dan Teknik, Universitas Jenderal Soedirman \\ Purwokerto, Indonesia \\ E-mail: agung_nghp@yahoo.com
}

\begin{abstract}
This paper tracks the history of Euclid's fifth postulate or parallel postulate. It is a long term postulate and dificult to be understood, and can evoke misunderstanding. Moreover, this postulate had evoked discourse among mathematicians about its dependency with other postulates for a long time untill the 19th century. The discourse related to assuredness of mathematician after Euclid's era is whether or not Euclid's fifth postulate can be deduced from other four postulates. But, the discourse became precisely a cause of finding of new geometry system, called non-Euclide geometry.
\end{abstract}

Keywords: dependancy, discourse, Euclid's parallel postulate

\section{Pendahuluan}

Geometri merupakan bidang matematika yang pertama kali dikembangkan secara aksiomatik, dan itu dilakukan oleh Euclid dari Yunani (yang kemudian menetap di Aleksandria, Mesir yang pada saat itu di bawah kekuasaan Yunani). Geometri yang dikembangkan oleh Euclid dengan sistem aksiomatik melalui lima postulatnya, belakangan dikenal sebagai geometri Euclid.

Geometri Euclid telah merajai dunia ilmu pengetahuan lebih dari satu milenium (seribu tahun), hingga akhirnya Rene Descartes memperkenalkan geometri analitik melalui sistem koordinat yang menempatkan sebuah titik sebagai pasangan terurut dari dua atau tiga bilangan. Akan tetapi, geometri analitik Descartes bukanlah jenis geometri baru. Geometri tersebut hanyalah bentuk analitik dari geometri Euclid. Karena geeometri Euclid saat ini masih diajarkan di sekolah-sekolah, maka geometri Euclid telah lebih dari 2000 tahun dipelajari oleh umat manusia.

Euclid menyusun geometrinya dengan menggunakan lima buah postulat. Empat postulat yang pertama tidak menimbulkan polemik (diskursus), namun berbeda dengan postulat kelima yang menimbulkan diskursus berkepanjangan hingga abad ke-19. 
Postulat kelima Euclid yang diterima tanpa melalui pengujian dan pembuktian, menimbulkan banyak pertanyaan dan ketidakpastian bagi para matematikawan masa itu dan mendorong perlunya dilakukan studi mengenai postulat kelima tersebut. Studi dilakukan dalam rangka membuktikan bahwa postulat kelima adalah suatu teorema yang diturunkan dari empat postulat lainnya. Terdapat dua metode untuk membuktikannya yaitu pembuktian langsung dan tidak langsung.

Pembuktian langsung ditempuh dengan cara merumuskan postulat kelima Euclid dalam format baru sebagai teorema kesejajaran, yang jauh lebih sederhana dibanding postulat kelima Euclid, dan kemudian membuktikan teorema kesejajaran tersebut dengan menggunakan empat postulat lainnya. Pembuktian tidak langsung dilakukan dengan cara merumuskan postulat kelima Euclid dalam format baru sebagai teorema kesejajaran, kemudian menegasikan teorema kesejajaran tersebut dan membuktikannya dengan menggunakan empat postulat lainnya melalui pembuktian dengan kontradiksi atau reductio ad absurdum.

Rentang waktu yang sangat lama untuk sebuah diskursus menjadi motivasi bagi penulis untuk merekam perjalanan diskursus tersebut dari waktu ke waktu. Hasilnya dipaparkan dalam artikel ini, sehingga artikel ini disusun untuk menjawab permasalahan apakah postulat kelima (postulat kesejajaran) adalah suatu postulat ataukah berupa teorema, atau apakah Euclid telah keliru menempatkannya sebagai postulat dan jika benar suatu teorema, mengapa Euclid tidak cukup pintar memperoleh buktinya tetapi justru menyatakannya sebagai suatu postulat saja.

Diskursus tersebut pada akhirnya menyadarkan dan menginspirasi akan kemungkinan terdapatnya sistem geometri lain yang tidak didasarkan pada postulat kesejajaran Euclid. Kesadaran tersebut sesungguhnya sudah tertuang dalam karya-karya Saccheri dan Gauss (tidak dipublikasikan), namun baru dapat diwujudkan oleh Lobachevsky, Janos Bolyai dan Bernhard Riemann sebagai kreator yang membidani kelahiran geometri non-Euclid. 
Artikel ini merupakan kajian pendahuluan yang dilakukan penulis dalam rangka mempelajari sejarah kelahiran geometri hiperbolik dan geometri eliptik sehingga sidang pembaca dapat menggunakan artikel ini untuk keperluan yang sama. Manfaat lain yang dapat diserap adalah motivasi, inspirasi dan semangat para matematikawan dari jaman ke jaman yang tidak pernah mati sebagai hikmah yang sangat berharga bagi pekerja matematika.

\section{Hasil dan Pembahasan}

Euclid (325-265 SM) diyakini sebagai yang menulis the Elements. The Elements atau Euclid Elements atau the Elements of Geometry yang memuat lebih dari 450 proposisi (http://math.widulski.net/slides/CH04_GreeksBearingGifts.ppt) dan sumber lain menyebutkan 465 proposisi (http://mtsu32.mtsu.edu:11208/Chap11Pres.ppt) dapat dikatakan sebagai puncak tradisi Yunani klasik dalam bidang matematika teoritis. Dengan sangat hati-hati, Euclid mengatur dan mengompilasi semua pengetahuan geometri yang penting yang telah diketahui pada masa itu dalam tigabelas jilid the Elements. Hasil kerja Euclid berisi pengetahuan yang telah diperoleh Pythagoras (580-500 SM), Plato (428-348 SM), Eudoxus, dan Hippocrates, sehingga the Elements dapat disebut sebagai karya kompilasi seluruh pengetahuan matematika yang telah diketahui pada saat menyusun the Elements (http://math.widulski.net/slides/CH04_GreeksBearingGifts.ppt). Sebagai penghormatan kepadanya, geometri yang tertuang dalam buku the Elements disebut geometri Euclid. Geometri inilah yang diajarkan sejak sekolah dasar sampai perguruan tinggi. Tidak dipungkiri bahwa sumbangan Euclid sendiri tidak kalah banyaknya, dapat disebutkan antara lain Algoritma Euclid untuk menentukan Faktor Persekutuan Terbesar (Greatest Common Divisor) dari dua buah bilangan asli. 

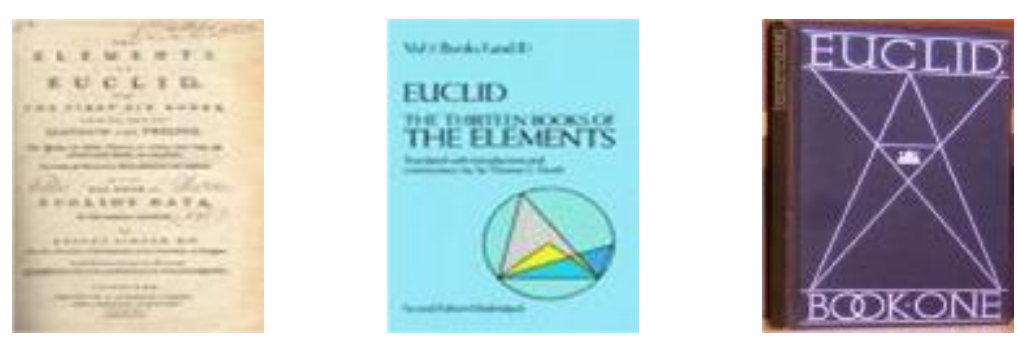

Gambar 1. The Elements: dari Masa ke Masa http://www.yorku.ca/bwall/math5400/projects/euclid.ppt

The Elements disusun secara deduktif dalam bentuk sistem aksiomatik dalam tigabelas buku atau volume. Pernyataan-pernyataan dimulai dengan suatu aksioma atau postulat dan dirangkai dengan teorema yang selalu didasarkan pada pernyataan sebelumnya. Struktur dari ketiga belas buku the Elements adalah sebagai berikut (http://www.yorku.ca/bwall/math5400/projects/euclid.ppt):

1. Empat buah buku pertama membahas geometri bidang berupa segitiga, segiempat, lingkaran, segibanyak, perbandingan dan kesebangunan.

2. Enam buku berikutnya (buku ke-5 sampai ke-10) membahas teori bilangan. Secara khusus, buku ke-5 merupakan karya Eudoxus, buku ke-7 adalah karya asli Euclid berupa pengenalan teori bilangan yang memuat Algoritma Euclid, buku ke-8 membahas deret geometri dan buku ke-10 membahas bilangan irasional.

3. Tiga buku terakhir membahas geometri ruang. Secara khusus, buku ke-12 membahas limas, kerucut, dan tabung. Sedangkan buku ke-13 membahas bidang banyak beraturan yang disebut benda-benda Platonik (Platonic Solids) yaitu heksahedron, tetrahedron, oktahedron, dodekahedron dan ikosahedron. 
The Elements diterbitkan di Eropa pertama kali tahun 1482 (http://math.widulski.net/slides/CH04_GreeksBearingGifts.ppt). Dampak dari the Elements sangat luar biasa, antara lain metode aksiomatik-deduktif Euclid juga digunakan dalam buku Isaac Newton berjudul Principia dan buku Immanuel Kant berjudul Critique of Pure Reason. Presiden AS, Abraham Lincoln menguasai enam buku pertama the Elements dengan tujuan untuk meningkatkan keterampilan penalarannya, sedangkan Albert Einstein menggambarkan the Elements sebagai keajaiban kedua dalam hidupnya. Setelah dua puluh tiga abad ditulisnya the Element, siswa-siswa di seluruh dunia masih belajar geometri Euclid berdasarkan buku tersebut.

\subsection{Postulat Kelima Euclid}

Dari tigabelas volume (buku) the Elemenst, postulat kelima Euclid yang terdapat pada volume pertama merupakan postulat yang memicu terjadinya polemik. The Elements volume pertama memuat 23 definisi, 48 proposisi, dan sepuluh aksioma (http://mtsu32.mtsu.edu:11208/Chap11Pres.ppt). Euclid membagi sepuluh aksioma menjadi lima postulat dan lima common-notions. Lima buah common-notions tersebut adalah (Pinillos; Kalimuthu, 2009) :

1. Segala sesuatu yang sama/sejenis dengan sesuatu lainnya, maka masing-masing satu sama lain juga akan sama/sejenis.

Hal ini berarti jika $a=c$ dan $b=c$, maka $a=b$

2. Jika segala sesuatu yang sama/sejenis ditambahkan kepada segala sesuatu yang sama pula, maka hasil keseluruhannya akan sama/sejenis. Hal ini berarti jika $a=b$, maka $a+c=b+c$

3. Jika segala sesuatu yang sama/sejenis dikurangkan dengan sesuatu yang sama/sejenis, maka sisanya sama/sejenis.

Hal ini berarti jika $a=b$, maka $a-c=b-c$

4. Segala sesuatu yang saling menyatu, maka masing-masing satu sama lain juga akan sama/sejenis

Hal ini berarti $a=a$

5. Keseluruhan lebih besar daripada kumpulan bagiannya. 
Keempat postulat pertama Euclid bersifat trivial (bermakna tunggal) dan secara intuitif kebenarannya bersifat self-evident dan sesuai dengan akal sehat (common sense). Berikut ini adalah empat postulat Euclid (Hamilton; Pinillos; Kezys, 2005; Hoard, 2009; Kalimuthu, 2009):

1. Sebuah garis lurus dapat dibuat dari sebarang dua titik yang berbeda.

2. Memperpanjang garis lurus yang terhingga secara terus-menerus pada akhirnya yang akan diperoleh sebuah garis lurus pula

3. Sebuah lingkaran dapat dibuat dari sebarang titik pusat dengan sebarang jari-jari tertentu.

4. Semua sudut yang dibuat oleh dua garis lurus yang berpotongan tegak lurus akan sama besarnya.

Sementara itu, postulat kelima mampu menimbulkan kegelisahan yang kreatif. Apakah postulat kelima tersebut memang benar-benar suatu postulat ataukah teorema? Jika teorema, mengapa Euclid tidak cukup pintar memperoleh buktinya dan justru menyatakannya sebagai suatu postulat saja? Postulat kelima Euclid atau yang populer disebut postulat kesejajaran adalah sebagai berikut:

If straight line falling on two straight lines makes the interior angles on the same side less than two right angles, the two straight lines, if produced indefinitely, meet on that side on which are the angles less than the two right angles (http://www.uu.edu/dept/math/SeniorPapers/9798/.../Alicia\%20Tull.ppt; Hamilton; Chandrasekhar, 1989; Kalimuthu, 2009).

Euclid tidak pernah menyebut postulatnya tersebut dengan postulat kesejajaran. Jika dicermati dalam postulat kelima sama sekali tidak terkandung istilah kesejajaran. Euclid sendiri memberikan suatu definisi mengenai garis sejajar (parallel lines) sebagai berikut:

dua buah garis yang terletak pada satu bidang yang sama, jika diperpanjang terus (sampai tak hingga) pada kedua arahnya, maka kedua garis tersebut tidak akan bertemu (http://www.cst.cmich.edu/users/piate1k1/MTH_553_F07/noneuclidean_geometries_small.pdf). 
Adanya definisi ini mendukung argumentasi bahwa Euclid tidak pernah menyebut postulat kelimanya sebagai postulat kesejajaran. Postulat kelima memperoleh nama postulat kesejajaran karena postulat tersebut dapat disajikan dalam kalimat yang berbeda tetapi memiliki makna yang sama, sebagai berikut: melalui titik $\mathrm{P}$ yang terletak di luar garis $m$, terdapat paling banyak (tepat) satu garis yang melalui titik $\mathrm{P}$ dan sejajar dengan garis $m$. Postulat kesejajaran ini dipopulerkan oleh John Playfair (1748-1819), meskipun sesungguhnya sudah diungkapkan jauh hari oleh Proclus (410-485). Postulat Playfair itulah yang sekarang diberikan di ruang-ruang kelas dalam pembelajaran matematika.

\subsection{Diskursus Seputar Postulat Kelima Euclid}

Dikemudian hari, postulat kelima ini memicu perdebatan, diskursus atau polemik di antara para matematikawan, bahkan perdebatan tersebut sesungguhnya telah ada tidak lama setelah masa Euclid. Terlihat dengan jelas bahwa postulat kelima tersebut sangat berbeda dengan empat postulat lainnya, terutama karena kalimatnya yang sangat panjang sehingga sulit dimengerti dan sangat mudah menimbulkan pemahaman yang keliru atau berbeda di antara para ahli matematika.

Banyak matematikawan yang menganggap Euclid telah keliru menempatkannya sebagai postulat. Mereka mencurigai bahwa postulat kelima Euclid tersebut sesungguhnya teorema yang harus dibuktikan kebenarannya. Dengan kata lain, postulat kelima tersebut tidak independen, tetapi dapat dibuktikan, diturunkan atau tergantung pada empat postulat yang pertama.

Penyusunan postulat kelima dengan cara yang demikian, di lain pihak menunjukkan bahwa Euclid adalah seorang jenius dalam matematika. Euclid pun tidak memberikan bukti terhadap postulat kelima tersebut, sebab bagi Euclid sendiri, karena pernyataan tersebut adalah postulat, maka benar dengan sendirinya sehingga tidak perlu bukti apapun. Para ahli yang berpendapat bahwa postulat kelima Euclid merupakan suatu teorema, tidak ada satu pun yang berhasil memberikan buktinya, sehingga tampaklah keunggulan dan kejeniusan Euclid dibanding ahli-ahli matematika sejamannya atau bahkan sesudahnya. 
Usaha untuk membuktikan postulat kelima dimulai segera sesudah Euclid merumuskan sistem geometrinya. Hal tersebut dilakukan dengan merumuskan postulat kelima Euclid dalam proposisi yang baru dan menganggapnya sebagai suatu teorema (teorema kesejajaran) untuk kemudian dibuktikan kebenarannya, atau dengan menegasikannya dan menunjukkan negasinya salah. Beberapa diantaranya adalah Poseidonius (135-51 SM), Claudius Ptolemy (85-165), Proclus (410-485), Ibnu al-Haytam atau Alhazen (965-1039), Omar Khayyam (1048-1131), Nasir Eddin (al-Din) at-Tusi (1201-1274) dan anaknya Sad'r al-Din at-Tusi, John Wallis (1616-1703), Girolamo Saccheri (1667-1733), John Playfair (1748-1819), Johann Heinrich Lambert (1728-1777), dan Adrien Marie Legendre (1752-1833), Wolfgang Farkas Bolyai (1775-1856) dan Carl Friederich Johann Gauss (1777-1855).

Usaha tersebut tidak ada yang membuahkan hasil, sehingga nampaklah keunggulan geometri Euclid. Namun diluar kesadaran mereka semua, usaha tersebut di kemudian hari justru memunculkan sistem geometri lainnya yang sekarang dikenal dengan geometri non-Euclid (geometri hiperbolik dan geometri eliptik). Geometri non-Euclid juga masih mendasarkan pada keempat postulat pertama Euclid, hanya berbeda pada postulat kelima mengenai kesejajaran. 


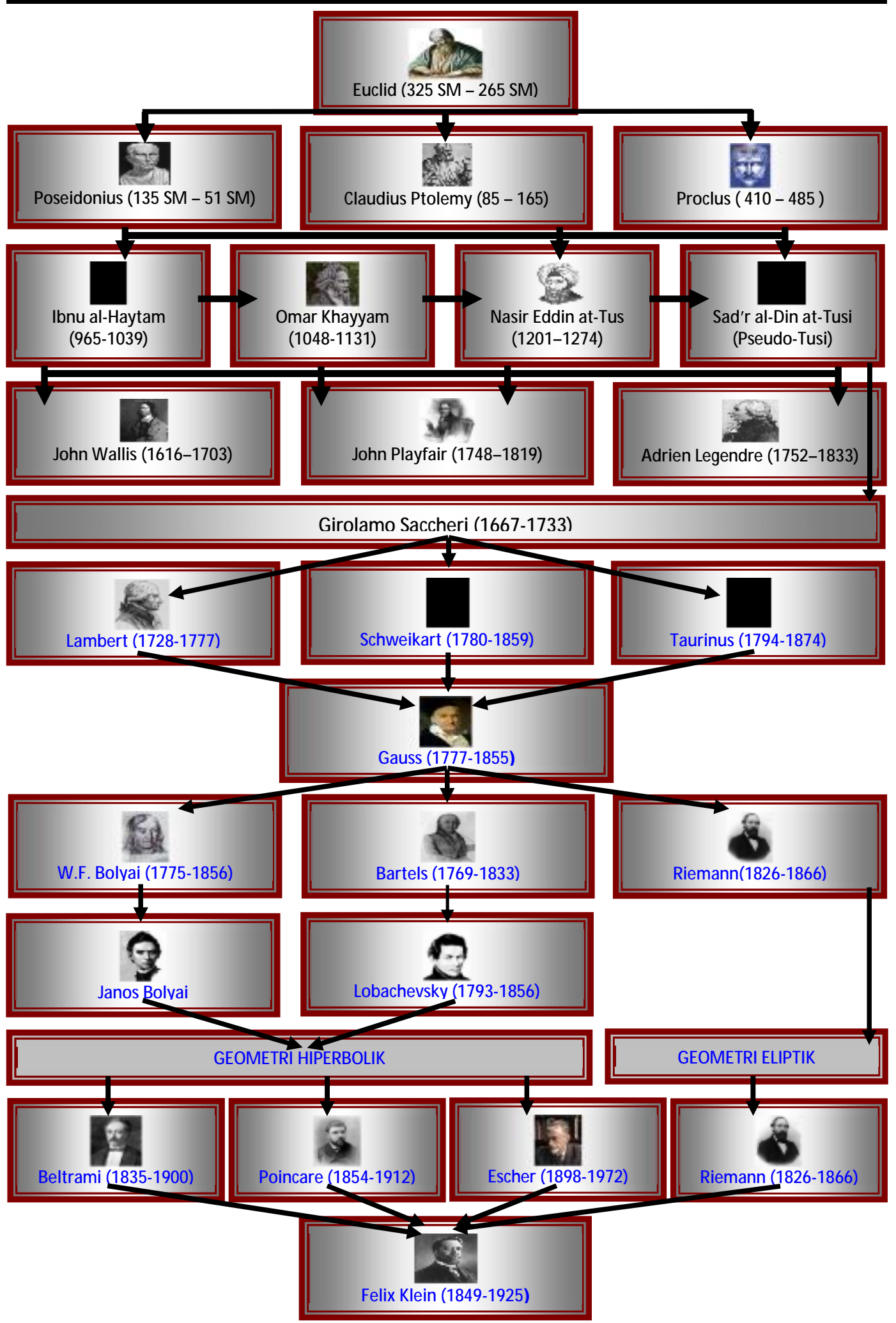

Gambar 2. Peta Sejarah Perkembangan Geometri via Matematikawan (http://cerezo.pntic.mec.es/mgarc144/marcohistoria/The\%20Fifth\%20Postulate.pdf) 
Gambar 2 menampilkan peta sejarah perkembangan geometri dari geometri Euclid hingga ditemukannya geometri hiperbolik dan eliptik, termasuk diskursus postulat kelima, melalui tokoh-tokoh yang terlibat di dalamnya.

\subsubsection{Matematikawan Yunani}

Poseidonius (135-51 SM) merumuskan ulang postulat kelima Euclid dalam bentuk teorema dan berusaha membuktikannya dengan pernyataan $d u a$ garis yang berjarak sama (http://math.widulski.net/slides/CH04_GreeksBearingGifts.ppt). Sementara itu, Claudius Ptolemy (85-165) merumuskan ulang postulat kelima Euclid dengan pernyataan:

jika dua garis sejajar dipotong oleh garis transversal, maka jumlah sudutsudut dalam pada satu sisi akan sama dengan jumlah sudut-sudut dalam pada sisi lainya (http://mtsu32.mtsu.edu:11208/Chap11Pres.ppt).

Proclus (410-485) menulis sebuah buku berjudul Commentary (Chandrasekhar, 2009) yang menyatakan bahwa postulat kelima Euclid dapat dibuktikan dari postulat-postulat sebelumnya. Proclus sampai pada suatu bukti yang diinginkan, tetapi kemudian diketahui bahwa terdapat kesalahan dalam proses pembuktiannya. Menurut Proclus (410-485), postulat kelima Euclid dapat dinyatakan dengan dua pernyataan berikut ini:

garis-garis sejajar mempunyai jarak yang konstan satu dengan lainnya (http://mtsu32.mtsu.edu:11208/Chap11Pres.ppt).

melalui sebuah titik $\mathrm{P}$ di luar garis 1 ada tepat satu garis melalui $\mathrm{P}$ yang sejajar 1 (http://mtsu32.mtsu.edu:11208/Chap11Pres.ppt).

\subsubsection{Matematikawan Arab}

Matematikawan Arab dari Irak, Ibnu al-Haytam atau yang dikenal di Eropa dengan Alhazen (965-1039), berusaha membuktikan postulat kelima Euclid dengan metode kontradiksi. Al-Haytam membuat empat persegi panjang yang kemudian hari dikenal dengan nama Lambert's quadrilateral. 
Boris Abramovich Rozenfeld lebih memilih memberinya nama Ibnu alHaytam-Lambert quadrilateral (Kalimuthu, 2009). Pembuktian cara lain yang juga dilakukan oleh Al-Haytam adalah mirip dengan yang kemudian hari dirumuskan/dikenal sebagai Aksioma Playfair. Wajar jika diduga Lambert dan Playfair terinspirasi oleh al-Haytam.

Omar Khayyam adalah orang yang pertama kali memformulasikan postulat non-Euclid sebagai alternatif terhadap postulat kesejajaran Euclid. Dengan kata lain, Omar Khayyam adalah orang yang pertama kali menyatakan kemungkinan terdapatnya geometri baru yang bukan geometri Euclid. Jauh sebelum Saccheri menciptakan Saccheri quadrilateral, pada abad 11 Omar Khayyam telah menciptakan hal yang sama sehingga beberapa ahli menyebutnya tidak lagi dengan Saccheri quadrilateral tetapi dengan Khayyam-Saccheri quadrilateral (Kalimuthu, 2009). Hal ini terungkap dalam buku yang ditulisnya Book I of Explanations of the Difficulties in the Postulates of Euclid. Wajar jika diduga Saccheri mengambil inspirasi dari hasil pekerjaan yang dilakukan oleh Omar Khayyam.

Dalam membuktikan postulat kesejajaran, Omar Khayyam menggunakan proposisi yang ekuivalen dengan postulat kesejajaran Euclid berikut:

Two convergent straight line intersect and it is impossible for two convergent straight lines to diverge in the direction in which they converge (Kalimuthu, 2009).

Menurut Omar Khayyam, terdapat tiga kemungkinan yang berkaitan dengan postulat kelima Euclid, yaitu jika dua buah garis tegak lurus terhadap sebuah garis lain yang memotong keduanya, maka ujung-ujung kedua garis yang tegak lurus tersebut akan membentuk dua buah sudut dalam yang sama besarnya dengan tiga kemungkinan (1) kedua sudut dalam tersebut siku-siku (right), (2) kedua sudut dalam tersebut lancip (acute), dan (3) kedua sudut dalam tersebut tumpul (obtuse). 
Untuk dua kemungkinan yang terakhir (sudut lancip dan tumpul), Omar Khayyam meyakinkan dirinya bahwa dari keduanya hanya akan diperoleh kontradiksi-kontradiksi dengan hasil-hasil yang diperoleh dalam geometri Euclid, namun ia juga yakin bahwa kedua kemungkinan tersebut akan menghasilkan geometri baru. Kemudian hari terbukti bahwa kedua kemungkinan tersebut merupakan asumsi yang ekuivalen dengan postulat kelima Euclid.

Sesudah al-Haytham dan Omar Khayyam yang keduanya mengalami kegagalan, Nasir Eddin at-Tusi (1201 - 1274) juga bernasib sama. Nasir Eddin (al-Din) at-Tusi pada tahun 1250 menulis sebuah buku berjudul Al-Risala alShafiya'an al-Shakk fi'l-Khutut al-Mutawaziya (Discussion Which Removes Doubt about Parallel Lines) yang berisikan kritikan terhadap postulat kesejajaran Euclid dan pembuktian yang telah dilakukan oleh Omar Khayyam sekitar satu abad sebelumnya (Kalimuthu, 2009).

At Tusi membuktikan postulat tersebut dengan metode reductio ad absurdum atau pembuktian dengan kontradiksi. Hasil yang diperoleh at Tusi, beberapa tahun kemudian disempurnakan oleh anaknya, Sad'r al-Din (terkadang disebut Pseudo-Tusi). Berdasarkan hasil pemikiran bapaknya, Sad'r al-Din mencurahkan hasil kerjanya ke dalam sebuah buku yang terbit tahun 1298. Buku tersebut memberikan argumentasi-argumentasi paling awal mengenai hipotesa non-Euclid yang ekuivalen dengan postulat kelima Euclid. Sad'r al-Din juga merevisi aksioma-aksioma dan postulat-postulat dalam geometri Euclid serta memperbaiki beberapa bukti dari proposisi-proposisi dalam buku the Elements. Hasil kerja Sad'r al-Din ini diterbitkan di Roma, Italia pada tahun 1594 dan dipelajari oleh para ahli geometri Eropa, termasuk oleh Girolamo Saccheri. Buku Sad'r al-Din tersebut yang menjadi dasar bagi Girolamo Saccheri, seorang profesor matematika di Universitas Pavio, Italia, dalam membuktikan postulat kelima Euclid. 
Giordano Vitale (1633-1711) yang menulis buku berjudul Euclid Restituo (1680 dan 1686) juga menggunakan ide dalam buku Sad'r al-Din mengenai Khayyam-Saccheri quadrilateral untuk membuktikan pernyataan:

jika tiga titik mempunyai jarak yang sama terhadap alas (base) $\overline{A B}$ dan atap (summit) $\overline{C D}$, maka $\overline{A B}$ dan $\overline{C D}$ di manapun akan berjarak sama (Kalimuthu, 2009).

\subsubsection{Matematikawan Eropa}

Pada tahun 1663, John Wallis (1616-1703), profesor dari Oxford University (Pinillos) mencoba membuktikan postulat kelima Euclid berdasarkan empat postulat sebelumnya. Wallis menduga, namun keliru, bahwa ia telah berhasil membuktikan postulat kelima Euclid, dengan cara membuktikan pernyataan yang bersesuaian maknanya dengan postulat kelima Euclid yaitu:

untuk setiap segitiga, akan terdapat sebuah segitiga sebarang yang sama ukurannya (http://www.yorku.ca/bwall/math5400/projects/euclid.ppt).

misalkan diberikan sebuah segitiga $\mathrm{ABC}$ dan segmen $\mathrm{DE}$, maka ada sebuah segitiga DEF yang sebangun dengan segitiga ABC (http://www.yorku.ca/bwall/math5400/projects/euclid.ppt)

John Playfair (1748-1819) memberikan format baru postulat kelima Euclid dengan sangat indah dan sederhana. Dengan postulatnya, Playfair mencoba untuk mengonstruksi postulat kesejajaran yang dikemukakan oleh Euclid sehingga lebih mudah dipahami dalam dua buah pernyataan yaitu:

dua garis lurus yang berpotongan tidak akan sejajar satu sama lain (http://mtsu32.mtsu.edu:11208/Chap11Pres.ppt).

melalui suatu titik $\mathrm{P}$ yang terletak di luar garis $\mathrm{m}$, terdapat paling banyak (tepat) satu garis yang akan melalui titik $\mathrm{P}$ dan sejajar dengan garis $\mathrm{m}$ (Hamilton; Pinillos; http://math.widulski.net/slides/CH04_GreeksBearingGifts.ppt.). 
Johann Lambert (1728-1777), pada tahun 1766, juga berharap untuk dapat membuktikan bahwa postulat kelima Euclid salah sehingga dapat diperoleh geometri yang berbeda. Ia bekerja dengan cara yang sama seperti dilakukan oleh Saccheri dan juga tidak pernah sukses di dalam pembuktiannya. Hasil kerjanya tidak pernah dipublikasikan, kecuali setelah kematiannya (http://wwwmath.cudenver.edu/ wcherowi/courses/m3210/lecchap9.pdf) pada tahun 1786 berjudul Theory of Parallels. Lambert memberikan pernyataan yang sepadan dengan postulat kelima Euclid sebagai berikut:

sebuah sisi empat dengan tiga buah sudut siku-siku adalah persegi panjang (http://mtsu32.mtsu.edu:11208/Chap11Pres.ppt

Seperti dinyatakan oleh Klugel (1739-1812), Lambert sangat terbiasa dengan hasil-hasil pekerjaan Saccheri. Lambert menciptakan segiempat yang sekarang dikenal sebagai segiempat Lambert dengan tiga buah sudutnya siku-siku. Selanjutnya ia merumuskan suatu hipotesa mengenai besar sudut yang keempat (Chandrasekhar, 1989) yaitu: (i) siku-siku, (2) tumpul, dan (3) lancip. Metode yang digunakan Lambert mirip yang dilakukan oleh Saccheri. Hasil investigasi Lambert memuat bagian yang sangat menarik. Ia menyatakan bahwa akan diperoleh hasil-hasil yang saat ini dikenal dengan geometri sperik (eliptik) jika hipotesa kedua (sudut puncak tumpul) valid dan bahwa hasil-hasil tersebut saling bebas (tidak tergantung) pada postulat kesejajaran Euclid.

Adrien-Marie Legendre (1752-1833), pada tahun 1794, menulis Elements de Geometrie (http://www.math.uconn.edu/ kaufmann/math242Wf04/Lecture3.ppt). Dalam publikasinya, Legendre menulis ulang proposisi-proposisi Euclid dari buku the Elements dengan lebih sederhana. Legendre juga berusaha untuk membuktikan bahwa postulat kelima Eucldi dapat dideduksi (dibuktikan) dengan menggunakan keempat postulat lainnya. Pada akhirnya, Legendre sampai pada suatu pernyataan yang ekuivalen dengan postulat kelima Euclid. Namun, Legendre tidak berhasil membuktikan bahwa postulat kelima Euclid independen terhadap keempat postulat lainnya. 
Legendre menggunakan dua buah proposisi yaitu:

sebuah garis yang melalui suatu titik yang terletak pada interior suatu sudut yang lebih besar dari sudut siku-siku, akan memotong paling tidak salah satu dari sisi sudut tersebut (http://math.widulski.net/slides/CH04_GreeksBearingGifts.ppt).

jumlah sudut-sudut segitiga besarnya dua kali sudut siku-siku (Pinillos; http://www.math.uconn.edu/ kaufmann/math242Wf04/Lecture3.ppt).

Dalam rangka membuktikan postulat kelima Euclid, Legendre mengajukan tiga masalah yang saling lepas, yaitu jumlah sudut-sudut segitiga akan (1) lebih besar dari dua sudut siku-siku, (2) dua kali sudut siku-siku, dan (3) lebih kecil dari dua sudut siki-siku (Chandrasekhar, 1989). Berkaitan dengan masalah pertama, dihasilkan banyak kontradiksi dan untuk masalah ketiga, setelah mencoba dalam waktu yang lama untuk memperoleh kontradiksinya, tetap saja menemukan kegagalan. Argumen-argumen yang diberikan berkaitan langsung dengan hasilhasil yang diperoleh Saccheri dan Lambert.

Semua studi tentang kesejajaran Euclid pada dasarnya tetap mendukung kebenaran postulat kelima Euclid dan semakin meyakinkan bahwa postulat kelima Euclid bukanlah suatu pernyataan yang kebenarannya harus dibuktikan. Upaya seluruh ahli matematika dalam menunjukkan bahwa postulat kelima Euclid sesungguhnya adalah suatu teorema tidak pernah ada yang berhasil. Namun, upaya mereka tidaklah sia-sia. Masih ada penerus lain yang akan terus tertarik bermain-main dengan postulat kelima Euclid. Kegagalan mereka akhirnya semakin mengukuhkan dominasi Euclid sehingga geometri yang didasarkan pada kelima buah postulat Euclid dikenal sebagai geometri Euclid. Kemudian hari, postulat kelima Euclid yang terlalu panjang, dalam pembelajaran matematika di sekolah diganti dengan postulat kesejajaran (atau postulat Playfair) yang dirumuskan oleh Proclus namun dipopulerkan oleh John Playfair. 


\section{Girolamo Saccheri}

Beberapa sumber menyebutkan Saccheri (1667-1733) adalah seorang sarjana yang berprofesi sebagai guru (Hamilton) namun sumber lainnya menyebutkan ia adalah profesor di Pavia University (Pinillos). Saccheri melakukan terobosan yang berani dan radikal dalam membuktikan postulat kelima Euclid sebagai suatu teorema dengan dua cara (1) menggunakan 28 proposisi Euclid yang pertama dan (2) menolak postulat kesejajaran Euclid melalui metode kontradiksi. Saccheri menyatakan ulang postulat kelima Euclid dengan pernyataan:

jumlah sudut-sudut dalam dari suatu segitiga adalah dua kali sudut sikusiku (http://math.widulski.net/slides/CH04_GreeksBearingGifts.ppt).

Melalui cara yang kedua, Saccheri mengasumsikan postulat kelima adalah salah dan kemudian mencoba menunjukkan adanya suatu kontradiksi. Metode yang ditempuh Saccheri merupakan metode yang juga digunakan oleh Nasir Eddin at-Tusi, sekitar empat abad sebelumnya, dan yang sekarang disebut reductio ad absurdum atau metode absurd, yaitu jika diasumsikan postulat kesejajaran salah, dan kemudian dapat diperoleh kontradiksinya, ini berarti bahwa postulat kesejajaran tersebut harus benar. Dengan demikian, keempat postulat Euclid lainnya haruslah menyebabkan postulat kelima suatu teorema.

Cara yang dilakukan Saccheri tersebut adalah dengan merumuskan negasi dari postulat kesejajaran yang dirumuskan oleh Playfair melalui sebuah titik yang tidak terletak pada suatu garis, terdapat tepat sebuah garis sejajar yang melalui titik tersebut. Negasi dari postulat kesejajaran Playfair adalah melalui sebuah titik yang tidak terletak pada suatu garis, mungkin tidak ada garis yang sejajar dengan garis yang diberikan dan atau terdapat lebih dari satu garis yang sejajar dengan garis yang diberikan. 
Untuk membuktikan negasi tersebut, Sacheri mengasumsikan bahwa negasi dari postulat kelima Euclid adalah benar dan melakukan serangkaian langkah deduktif logis untuk membuktikan asumsinya tersebut salah.

Untuk menjelaskan pekerjaannya, Saccheri memperkenalkan segiempat Saccheri (Saccheri Quadrilateral) ABCD yang dua buah sudutnya siku-siku di A dan B dengan $\overline{D A}$ kongruen $\overline{C B}$, atau Segiempat Saccheri adalah segi empat $A B C D$ di mana $\angle D A B$ dan $\angle C B A$ merupakan sudut siku-siku dengan $\overline{D A} \cong$ $\overline{C B}$. Ruas garis $\overline{A B}$ disebut sebagai alas dan $\overline{C D}$ puncak (atap). Ini berarti pada segiempat $\mathrm{ABCD}$ berlaku $\angle A=\angle B=90^{\circ}$, sisi $\overline{A D}=\overline{B C}$ dan $\angle C$ sama dengan $\angle D$. Selanjutnya, dalam rangka mengkaji postulat kesejajaran, ia mengajukan tiga hipotesa berikut (Chandrasekhar, 1989; http://www.math.uconn.edu/ kaufmann/math242Wf04/Lecture3.ppt):

1. kedua sudut puncak tumpul (hypothesis of obtuse angle / HOA) $\left(\angle C\right.$ dan $\angle D$ lebih besar dari $90^{\circ}$ ) Hipotesa ini berkaitan dengan negasi pertama.

2. kedua sudut puncak siku-siku (hypothesis of right angle / HRA) ( $\angle C$ dan $\angle D$ sama dengan $90^{\circ}$ )

3. kedua sudut puncak lancip (hypothesis of acute angle / HAA) $\left(\angle C\right.$ dan $\angle D$ lebih kecil dari $\left.90^{\circ}\right)$ Hipotesa ini berkaitan dengan negasi kedua.

Pembuktian Saccheri membahas tentang sudut lancip dan sudut tumpul dari segiempat Saccheri. Pembuktian dengan sudut tumpul membawa hasil yang sangat tidak memuaskan, penuh dengan kontradiksi. Untuk kemungkinan pertama, Saccheri berhasil memperoleh kontradiksi, namun ia juga berhasil menunjukkan bahwa kemungkinan pertama tersebut, tidak mungkin dapat dibuktikan dengan keempat postulat Euclid, khususnya melalui postulat kedua. Ini berarti bahwa postulat kelima Euclid tetaplah suatu postulat. 
Pembuktian dengan sudut lancip membawa hasil yang cukup bagus. Saccheri berpikir bahwa ia telah berhasil menemukan kontradiksi postulat kelima Euclid, tetapi ia tidak pernah menyatakan bahwa postulat kelima Euclid terbukti benar karenanya. Tetapi pada akhirnya muncul masalah dalam pembuktiannya sehingga kontradiksi postulat kelima Euclid salah. Ini berarti Saccheri tidak dapat memperoleh suatu kontradiksi pada kemungkinan ketiga. Ia akhirnya menyatakan bahwa hipotesa sudut puncak lancip adalah kesalahan fatal, sebab tidak sesuai dengan sifat alami garis lurus. Secara keseluruhan, dengan metode reductio ad absurdum, Saccheri tidak berhasil menunjukkan bahwa postulat kelima merupakan suatu teorema. Saccheri tidak menyadari bahwa yang dilakukannya adalah menemukan geometri non-Euclid. Hasil temuannya kemudian menjadi dasar, ide atau gagasan baru untuk perkembangan Geometri Non-Euclid.

Hasil gemilang yang aneh diperoleh dari kemungkinan ketiga. Saccheri memperoleh hasil-hasil dan teorema yang sekarang terdapat dalam geometeri nonEuclid, misalnya bahwa jumlah kedua sudut puncak pada segiempat Saccheri adalah $90^{\circ}$, atau kedua sudut puncaknya merupakan sudut lancip (acute). Ini berarti jumlah semua sudut pada segiempat Saccheri adalah $270^{\circ}$ sehingga kurang dari $360^{\circ}$. Hasil ini sangat aneh dan bertentangan dengan geometri Euclid yang menyatakan jumlah sudut pada segiempat adalah $360^{\circ}$. Namun, Saccheri pun berhasil membuktikan bahwa jumlah sudut sebarang segitiga adalah $180^{\circ}$. Hasil ini ekuivalen dengan postulat kelima Euclid. Kedua hasil yang diperoleh Saccheri saling berkontradiksi, untuk segiempat bertentangan dan untuk segitiga bersesuaian. Akibatnya, Saccheri tidak berhasil menemukan adanya geometri baru, yang bukan geometri Euclid.

Walaupun sebenarnya beberapa ide dasar Saccheri telah terlebih dahulu diajukan oleh matematikawan Persia Omar Khayyam pada abad ke-11 dalam bukunya Omar Khayyam's Discussion of Difficulties in Euclid, tetap saja Saccheri dianggap sebagai peletak pondasi awal perkembangan geometri non-Euclid. 
Pada tahun 1733, setelah kematiannya, karya Saccheri yang berupa kumpulan teorema-teoremanya dipublikasikan dengan judul Euclid Freed of All the Imperfections atau Euclid Freed of Every Flaw (http://wwwmath.cudenver.edu/ wcherowi/courses/m3210/lecchap9.pdf). Buku tersebut, yang juga dikenal dengan Euclides Vindicatus, merupakan body of theorems bagi kemunculan geometri baru, sebuah buku yang kaya dengan gagasan-gagasan baru, meskipun gagasan tersebut nampak aneh.

Ide-ide mengenai kesadaran baru yang telah dimulai oleh Girolamo Saccheri, diteruskan oleh Johann Lambert, Schweikart, dan Taurinius. Ferdinand Karl Schweikart (1780-1859) dan Franz Adolf Taurinus (1794-1874) adalah dua orang amatir (bukan profesional) dalam matematika yang bersepupu. Schweikart, dalam waktu senggangnya, tahun 1816 membangun suatu geometri yang bebas (tanpa melibatkan) postulat kelima Euclid. Ia pun kemudian membagi keilmuan geometri ke dalam dua jenis: Geometri Euclid dan Geometri yang menolak kebenaran Postulat Ke-5 Euclid (atau Geometri non-Euclid). Sementara, sepupunya, Taurinus pada tahun 1824, mencapai apa yang disebutnya geometri hiperbolik yang bersifat non-Euclid.

\section{Wolfgang Farkas Bolyai}

Ada dua nama Bolyai dalam geometri yang keduanya adalah bapak dan anak. Sang bapak, Wolfgang Farkas Bolyai (1775-1856) adalah matematikawan Hungaria yang hidup sejaman dan berteman dengan Gauss dan terutama bersahabat melalui korespondensinya, dan anaknya Janos Bolyai diakui sebagai penemu geomtri hiperbolik, selain Lobachevsky. Tercatat pada tahun 1804, Farkas Bolyai mengirimkan kertas kerjanya kepada Gauss yang diberinya judul Theoria Parallelarium (Chandrasekhar, 1989) berisi mengenai pembuktian garisgaris lurus yang berjarak sama (equidistant straight line), yang tentunya masih berkaitan dengan postulat kelima Euclid. Sebagai orang yang penuh minat dan perhatian, Gauss memeriksanya dan menunjukkan masih adanya kesalahan. 
Farkas Bolyai memang tidak berhasil dalam membuktikan postulat kelima Euclid, tetapi ia telah memberikan pernyataan ulang postulat kelima Euclid tersebut:

Empat titik yang tidak sebidang, selalu berada pada sebuah sphere (http://mtsu32.mtsu.edu:11208/Chap11Pres.ppt).

Sebuah lingkaran dapat dibuat dari tiga buah titik yang tidak terletak pada satu garis lurus (http://mtsu32.mtsu.edu:11208/Chap11Pres.ppt)

Dengan demikian, adanya suatu lingkaran dapat digunakan sebagai langkah awal dalam melakukan investigasi postulat kesejajaran. Fakta ini digunakan oleh F.L. Wachter (1792-1817), salah seorang mahasiswa Gauss, untuk membuat beberapa pembuktian postulat kelima Euclid. Pada tahun 1816, Wachter menulis surat kepada Gauss yang diberinya judul Anti-Euclidean Geometry (Chandrasekhar, 1989). Menurut Wachter, jika postulat kelima Euclid keliru, maka akan terdapat sistem geometri baru yaitu geometri pada permukaan yang identik dengan bidang (ordinary plane). Pernyataan Wachter ini sangat penting untuk membangun geometri non-Euclid dan teori sudut lancip yang telah dikembangkan oleh Saccheri.

\section{Carl Friederich Johann Gauss}

Gagasan Saccheri sampai kepada Gauss melalui Lambert, Schweikart, dan Taurinius. Namun, tidaklah mudah untuk membidani lahirnya geometri jenis baru. Daya tahan geometri Euclid yang telah lebih dari 1000 tahun merajai matematika bukanlah pertahanan yang mudah dipatahkan. Bahkan Gauss pun yang sering disebut the Prince of Mathematicians tidak berani mempublikasikan karyanya mengenai geometri baru yang bukan geometri Euclid. Gauss mengklaim telah sampai pada penemuan kemungkinan adanya geometri baru tersebut, namun menyimpan hasil karyanya dan tidak pernah mempublikasikannya, lebih tepatnya merahasiakannya. 
Gauss menyadari akan adanya geometri baru, namun tetap saja ia gagal menjadi bidan atau creator yang pertama akibat karya-karyanya tidak dipublikasikan.

Carl Friederich Johann Gauss (1777-1855) adalah orang pertama yang mencurigai kemungkinan hasil yang diperoleh Saccheri mengenai sudut lancip tersebut tidaklah mungkin. Gauss sendiri sudah menekuni studi mengenai postulat kesejajaran sejak tahun 1792 ketika usianya baru 15 tahun, mencoba membuktikan postulat kelima dengan menggunakan keempat postulat lainnya. Kegagalan Gauss dalam pembuktiannya, dan sedikitnya kemajuan yang diperoleh dalam menekuni postulat kelima Euclid, membuatnya memutuskan untuk berubah haluan, dengan sebelumnya memberikan pernyataan ulang postulat kelima Euclid berupa Gauss's Alternate to the Parallel Postulate:

melalui sebuah titik yang terletak di luar suatu garis, terdapat sedikitnya dua buah garis yang melalui titik tersebut dan sejajar dengan garis yang diberikan (http://www.radford.edu/ wacase/math\%20116\%20section\%207.4\%20ne w\%20v1.pdf).

Gauss sendiri menyatakan bahwa semua yang diperolehnya dalam menekuni postulat kelima Euclid, tidak lebih baik dibanding apa yang telah diperoleh Euclid sendiri. Pada tahun 1813, saat memutuskan untuk meninggalkan kajian tentang kesejajaran, Gauss mengembangkan suatu geometri baru yang bersifat anti Euclid dan disebutnya geometri astral, yang akhirnya Gauss menyebutnya dengan geometri non-Euclid. Mungkin Gauss adalah orang yang pertama kali menemukan geometri non-Euclid, namun tanpa adanya pulikasi terhadap hasil yang diperolehnya, menyebabkan Janos Bolyai dan Lobachevsky yang lebih dikenal sebagai penemunya. Gauss juga merupakan matematikawan pertama yang menyatakan bahwa menegasikan postulat Euclid tidak akan pernah sampai kepada kontradiksi, dan sangat mungkin ada geometri lain selain geometri Euclid. 
Empat tahun kemudian, 1817, setelah memutuskan untuk mengakhiri mengkaji postulat kelima Euclid, Gauss kembali menjadi tertarik dan tertantang. Gauss meyakini bahwa postulat kelima bersifat bebas dari keempat postulat lainnya, artinya postulat kelima Euclid tidak dapat diturunkan, dideduksi dan dibuktikan dari empat postulat lainnya (http://math.boisestate.edu/ tconklin/.../Main/.../Noneuclidean\%20Geometry.ppt).

Salah satu hasilnya adalah terdapat lebih dari satu garis yang dapat dibuat melalui sebuah titik yang sejajar dengan suatu garis tertentu. Barangkali karena dominasi Imanuel Kant yang sangat kuat yang membuat Gauss tidak mempublikasikan karyanya untuk menghindari kontroversi. Namun demikian, Gauss diketahui melakukan diskusi mengenai kesejajaran dengan temannya yang matematikawan Hungaria, Farkas Bolyai. Dari diskusi itulah diketahui Gauss yang pertama-tama menggunakan istilah geometri non-Euclid dan memperkenalkan ide tentang surface curvature. Ide tentang surface curvature selanjutnya dijadikan dasar oleh Riemann di kemudian hari untuk mengembangkan geometri diferensial dan menjadi pondasi bagi Einstein dalam merumuskan teori relativitas umum.

Gauss mengajukan suatu teorema yang disebut Theorema Egregium atau Remarkable Theorem (http://math.boisestate.edu/ tconklin/.../Main/.../Noneuclidean\%20Geometry.ppt). Secara informal, teorema tersebut menyatakan bahwa curvature suatu permukaan dapat ditentukan dengan mengukur sudut dan jarak pada permukaan yang dimaksud, artinya tidak tergantung pada bagaimana permukaan ditampilkan dalam suatu ruang (tiga dimensi). Berdasarkan teorema tersebut, Gauss melakukan suatu eksperimen non-Euclid yang sangat luar biasa pada saat menjadi Kepala Komisi Survei Tanah di Swedia, tahun 1827. Dengan percobaan tersebut, Gauss ingin memberikan bukti empirik untuk geometri hiperbolik bahwa jumlah sudut segitiga kurang dari $180^{\circ}$. 
Ia mengukur suatu segitiga yang sangat besar yang dibuat pada puncakpuncak bukit Brocken, Hohehagen, dan Inselsberg. Sisi-sisi segitiga tersebut mempunyai panjang 43, 53, dan 67 mil atau 69, 85, dan 109 km. Hasilnya adalah jumlah sudut-sudut segitiga tersebut 180 derajat kurang 14,85 detik (http://math.boisestate.edu/ tconklin/.../Main/.../Noneuclidean\%20Geometry.ppt). Kekurangan tersebut dianggap terlalu kecil dibandingkan batas kesalahan pengukuran (batas keakuratan) sehingga eksperimen Gauss tidaklah berarti apaapa bagi pembuktian terhadap adanya geometri non-Euclid (geometri hiperbolik) secara empirik. Kemudian hari diketahui bahwa jika suatu segitiga dibuat di atas permukaan yang berbentuk kurva (tidak datar), jumlah sudut-sudutnya tidak tetap, tetapi tergantung pada panjang sisi-sisinya. Hasil observasi ini dituliskan Gauss dalam suatu kertas kerja berjudul General Investigations of Curved Surfaces. Di dalam karyanya tersebut, Gauss mengembangkan kajian yang saat ini disebut geometri diferensial sebab di dalamnya digunakan kalkulus diferensial untuk menentukan rumus yang digunakan dalam mengukur curvature suatu permukaan.

Dalam suratnya kepada Franz Taurinus, ditulis 1824, Gauss mengatakan bahwa ia begitu yakin kalau postulat kesejajaran tidak dapat dibuktikan melalui postulat-postulat $A$. Jika $P$ adalah postulat kesejajaran dan $H$ adalah negasinya, maka Gauss yakin bahwa $A \& H$ konsisten. Di kemudian hari, geometri yang dibangun dari $A \& H$ disebut geometri hiperbolik. Tahun 1839 Gauss menulis Scream of Dullards sebagai pintu mempelajari geometri non-Euclid.

\section{Kesimpulan dan Saran}

Artikel ini mengungkap fakta sejarah pergulatan matematikawan dan pekerja matematika dalam menjawab persoalan seputar kontroversi apakah postulat kelima Euclid benar-benar suatu postulat ataukah teorema. Fakta-fakta ini penting, tidak saja karena rentang waktu yang sangat lama namun juga kontroversi tersebut terjadi secara kontinum dan diminati serta menjadi perhatian banyak bangsa. 
Pentingnya kontroversi ini selain menghasilkan banyak pernyataan ulang untuk postulat kelima Euclid, juga menghasilkan postulat Playfair yang lebih elegan dan diterima oleh semua untuk menggantikan postulat kelima Euclid yang sangat panjang. Kontroversi ini pada akhirnya juga memunculkan kesadaran baru, meskipun sangat terlambat, bahwa terdapat system geometri lain yang dapat dibangun tanpa atau dengan mengganti postulat kelima Euclid. Kontroversi ini akhirnya mendorong ke arah penemuan geometri hiperbolik dan geometri eliptik, yang meskipun dianggap aneh dan tidak bermanfaat namun ternyata Einstein berterima kasih banyak atas penemuan geometri hiperbolik dan eliptik yang karenanya dapat ditemukan teori relativitas khusus dan umum.

Selain sebagai fakta sejarah, kontroversi ini juga mengajarkan bagaimana berpolemik dalam matematika, bagaimana menemukan ide-ide segar, saling memberi apresiasi dan pengakuan serta membentuk keyakinan untuk tidak pernah berhenti bekerja dan memberikan kontribusi nyata, baik yang abstrak maupun yang dapat langsung dirasakan manfaatnya oleh seluruh umat manusia.

Kajian sejarah matematika, selain mengungkap fakta juga mewariskan nilai-nilai, semangat, motivasi, inspirasi dan spirit sehingga yang seperti ini disarankan untuk juga dilakukan oleh para matematikawan dan pekerja matematika, termasuk juga oleh mahasiswa dan para murid.

\section{Daftar Pustaka}

Chandrasekhar, T.R., Non-Euclidean Geometry from Early Times to Beltrami, 1989, http://www.new.dli.ernet.in/rawdataupload/upload/insa/INSA_1/20005b60_ 249.pdf di akses pada 2 Desember 2009.

Hamilton, S., Non-Euclidean Geometries, http://webspace.ship.edu/kgmcgi/m400 /Presentations/Chapter\%2019.ppt., diakses pada 2 Desember 2009. 
Hoard, D., dan Chap, R., Non-Euclidean Geometry, 2009, http://nsfmli.rice.edu/presentations/2009\%20Summer\%20Presentations/NonEuclidean\%20Geometry\%20by\%20Ricardo\%20Chapa\%20\&\%20Daphne\%20Ho ard.pdf., diakses pada 2 Desember 2009.

Kalimuthu, S., The Parallel Postulate- Return of the Roaring Lion, 2009, http://indjst.org/archive/vol.2.issue.4/apr09kalimuth.pdf., diakses pada 6 April 2010.

Kezys, J., Shock of the New: The NonEuclidean Bases of Modern Art, 2005, http://math.mohawkcollege.ca/OCMA/conf05/Post_Conf05/john_Modern_\%20Ar t.pdf., diakses pada 2 Desember 2009.

http://math.boisestate.edu/ tconklin/.../Main/.../Noneuclidean\%20Geometry.ppt., diakses pada 3 Desember 2009.

http://math.widulski.net/slides/CH04_GreeksBearingGifts.ppt., diakses pada 3 Desember 2009.

http://mtsu32.mtsu.edu:11208/Chap11Pres.ppt., diakses pada 3 Desember 2009.

http://www.cst.cmich.edu/users/piate1kl/MTH 553 F07/non-euclidean_geometries _small.pdf., diakses 2 Desember 2009.

http://www.math.uconn.edu/ kaufmann/math242Wf04/Lecture3.ppt., diakses pada 2 Desmber 2009.

http://www-math.cudenver.edu/ wcherowi/courses/m3210/lecchap9.pdf., diakses pada 2 Desember 2009.

http://www.radford.edu/ wacase/math\%20116\%20section\%207.4\%20new\%20v1 .pdf., diakses 2 Desember 2009.

http://www.uu.edu/dept/math/SeniorPapers/97-98/.../Alicia\%20Tull.ppt., diakses pada 3 Desember 2009.

http://www.yorku.ca/bwall/math5400/projects/euclid.ppt., diakses pada 3 Desember 2009.

Pinillos, M.G., The History of the Fifth Postulate: the Birth of Non Euclidean Geometries, http://cerezo.pntic.mec.es/mgarc144/marcohistoria/The\%20Fifth\%20 Postulate.pdf., diakses pada 2 Desember 2009. 